\title{
ASSESSMENT OF LEAD AND CADMIUM IN SOME EGYPTIAN SALTED AND SMOKED FISH
}

\author{
NAHED M. ABDEL AZIZ* and Z.M. ZAKY** \\ * Department of Food Hygiene, Fac. of Vet. Med., Sohage University, Sohage, Egypt \\ ** Department of Forensic Medicine and Toxicology Fac. of Vet. Med, Assiut University, Assiut, Egypt. \\ Email: Nahedvet2012@yahoo.com
}

\section{ABSTRACT}

Received at: 11/12/2013

Lead $(\mathrm{pb})$ and cadmium (cd) were determined in muscle of salted fishes (Moloha and Feseakh), smoked fish (Ringa) and salted water (water of Moloha) collected from different markets in Sohage city during summer 2013. In this study, sixty random samples (15 each of Moloha, Feseakh, Ringa and salted water) were analyzed for determination of lead and cadmium level using a Graphite Atomic Absorption Spectrophotometer. Results showed that the mean concentration of $\mathrm{Pb}$ in muscle of Moloha, Feseakh and Ringa were 2.795 $\pm 0.419,2.890 \pm 0.512$ and $2.482 \pm 0.331$ while in salted water was $1.660 \pm 0.502(\mathrm{mg} / \mathrm{kg})$ respectively. The results showed also that the mean concentration of $\mathrm{Cd}$ in muscle of Moloha, Feseakh and Ringa were $0.024 \pm 0.018,0.406 \pm 0.138$ and $0.549 \pm 0.422$ while in salted water was $1.796 \pm 1.38(\mathrm{mg} / \mathrm{kg})$ respectively. It was concluded that the level of heavy metals $(\mathrm{Pb}$ and $\mathrm{Cd})$ in muscles of the three fish species were higher than the acceptable limits recommended by EOSQC, 1993 standards, except for Cd levels in muscles of Moloha fish $(0.024 \pm 0.018 \mathrm{~g} / \mathrm{kg})$. The implications and public health concerns are hereby discussed.

Key words: Lead, Cadmium, Salted and Smoked Fish.

\section{INTRODUCTION}

Fish are often at the top of aquatic food chain and may concentrate large amounts of some metals from the water. Marine invertebrates are exposed to metals from both dissolved and particulate phases. Metals can be accumulated by animals following ingestion and digestion of food (Yilmaz et al., 2007).

Heavy metals such as lead and cadmium are constituting a significant potential threat to human health, both occupational and environmental $(\mathrm{Hu}$, 2000). Lead occurs naturally in the environment, and may be contaminate water from industrial and agricultural discharges, high ways or motor traffic (Sorensen, 1991). Lead residues may lead to neurological and gastrointestinal dysfunction, increase blood pressure, cardiovascular disease and alter cellular calcium metabolism (Elinder, 1985). Impairments specifically related to lead toxicity in humans include abnormal size and decrease of erythrocytes hemoglobin content, hyperstimulation of erythropoiesis and inhibition of haeme synthesis (Mansour and Sidky, 2002).

Cadmium and its compounds are toxic to humans, wildlife, and especially aquatic biota, at low concentrations The excess of cadmium intake under certain conditions may cause renal hypertension. Some authors have already observed that cadmium alters calcium homeostasis (Pratap and Wendelaar,
2007) also cadmium toxicity resulted in osteomalacia (Friberg 1984).

Salting is one of the earliest and most widespread preservation technique practiced by man (Wheaton and Lawson, 1985), it is used as commonly traditional method in some Mediterranean areas and tropical countries because of simplicity of the process, low production cost and its ability to be combined with other methods in order to satisfy consumer's habit and requirements (Berhimpon et al., 1991). It is well known that fish salting is a process which aims to reach the saline equilibrium between fish muscle and the surrounding salt solution in a specific time (Zugarramurdi and Lupin, 1980). Two salted fish specialities that are exclusively Egyptian Feseekh and Moloha.

Feseekh is traditionally eaten during Sham El Neseem feast ("Smelling the Breeze"), which is a spring celebration from ancient times in Egypt and it was selected as one of the widely consumed salted fish product, of great preference among Egyptian consumers. Moloha is considered a delicacy in the south (Upper Egypt). Produced by freshwater fish and it is known to be very salty (Yosef and Ghada, 2011).

Smoking is one of the traditional fish processing methods aimed at preventing or reducing post harvest losses. Therefor, the object of the present study was to determine the levels of lead and cadmium in muscles of salted and smoked fish in addition to 
salted water for Moloha (s.w.) with their relation to public health hazard.

\section{MATERIALS and METHOD}

\section{Sampling:}

A total of sixty random samples, 15 each of salted fish (Moloha and Feseakh), smoked fish (Ringa) and salted water (water of moloha) were collected from different markets in Sohage city during summer 2013. Heavy Metals (lead and cadmium) were determined by using a ZEE nit 700P Atomic Absorption Spectrophotometer (AAS) with Graphite furnace. 0.5 gm of each sample was weighed into a set of digestion microwave tubes. Ten $\mathrm{ml}$ of nitric acid was mixed into the sample vessels. Mixture of content of the digestion tubes were then digested by Microwave oven at a temperature of $60^{\circ} \mathrm{C}$ for $30 \mathrm{~min}$. The digestion was allowed to cooling at room temperature. Thereafter, samples were diluted with ultra-pure water to make a volume of $25 \mathrm{ml}$, put in clean glass vials and kept till analysis.

The combined stock $(\mathrm{Pb}$ and $\mathrm{Cd}$ standard $100 \mathrm{ppm}$ each) were prepared from reference standards and stored in the refrigerator until use. The method of calibration curve was used for calibration and quantification of the AAS to its effective position. The working standards were first determined to create the standard curve; this was followed by the measurement of the unknown analyte. The Atomic Absorption Spectrophotometer was adjusted to specific wavelength corresponding to each of the metals to be measured.

\section{Statistical Analysis:}

Statistical analysis was performed using Agrafic Pad Prism. Analysis of Variance (ANOVA) was used and statistical significance was set at $\mathrm{P}<0.05$. Duncan Multiple Range Test was used to separate differences in treatment means (Steel et al., 1996).

\section{RESULTS}

Table 1: Minimum, maximum and mean $( \pm \mathrm{SD})$ levels of lead in muscle of Moloha, Feseakh, Ringa and Preserved salted water.

\begin{tabular}{lccc}
\hline Fish speacies & Minimum & Maximum & Mean \pm SD \\
\hline Moloha & 2.247 & 3.481 & $2.795 \pm .0 .419$ \\
\hline Feseakh & 2.006 & 3.668 & $2.890 \pm 0.512$ \\
\hline Ringa & 1.672 & 2.903 & $2.482 \pm 0.331$ \\
\hline salted water & 1.072 & 2.833 & $1.660 \pm 0.502$ \\
\hline
\end{tabular}

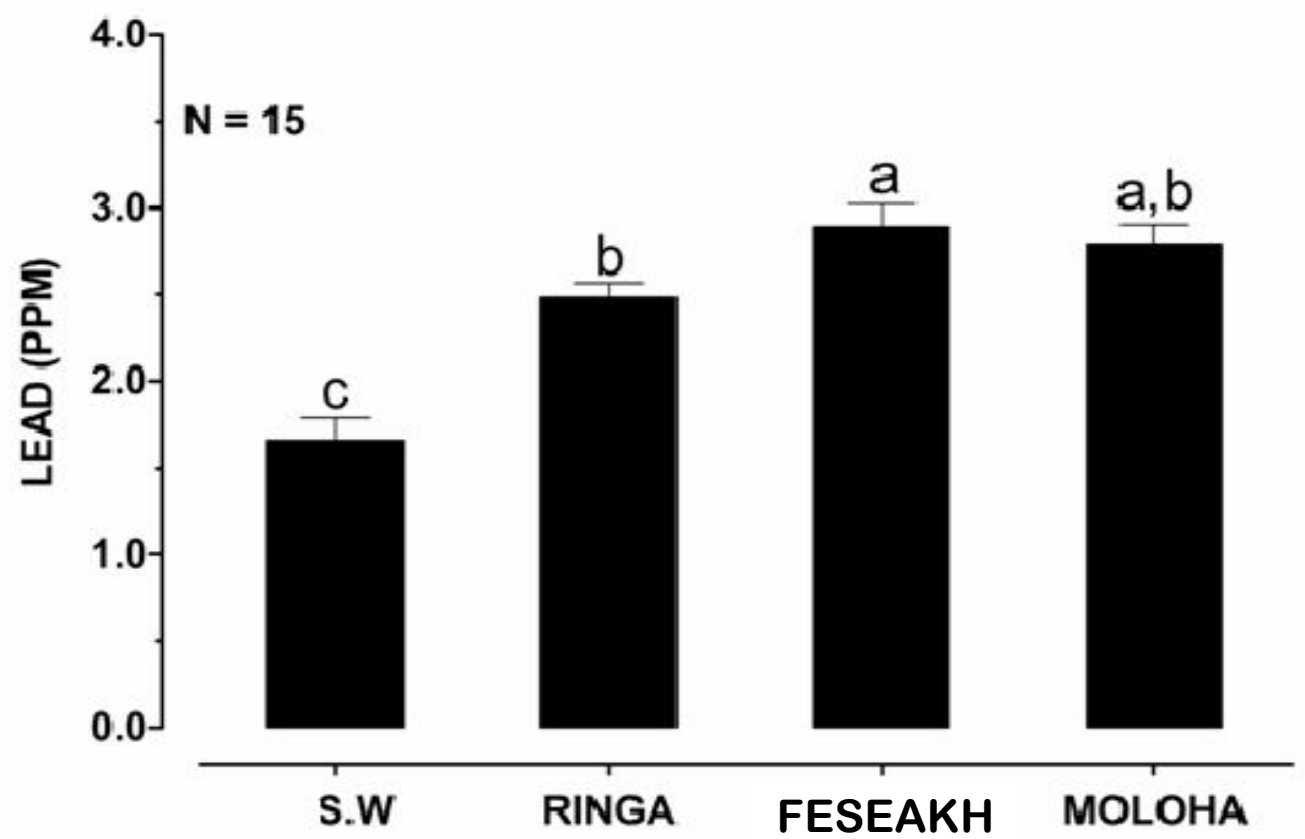

Figure (1) lead levels in different types of fishes $n=15$ The letters on bar a,b,c denotes the significance difference of lead levels among the different types of fishs $(\mathrm{P}<0.05)$ 
Table 2: Minimum, maximum and mean $( \pm \mathrm{SD})$ levels of cadmium in muscle of Moloha, Feseakh, Ringa and Preserved salted water.

\begin{tabular}{lccc}
\hline Fish species & Minimum & Maximum & Mean \pm SD \\
\hline Moloha & 0.178 & 0.354 & $0.24 \pm 0.018$ \\
\hline Feseakh & 0.147 & 0.664 & $0.406 \pm 0.138$ \\
\hline Ringa & 0.163 & 1.519 & $0.549 \pm 0.422$ \\
\hline salted water & 0.596 & 4.108 & $1.796 \pm 1.38$ \\
\hline
\end{tabular}

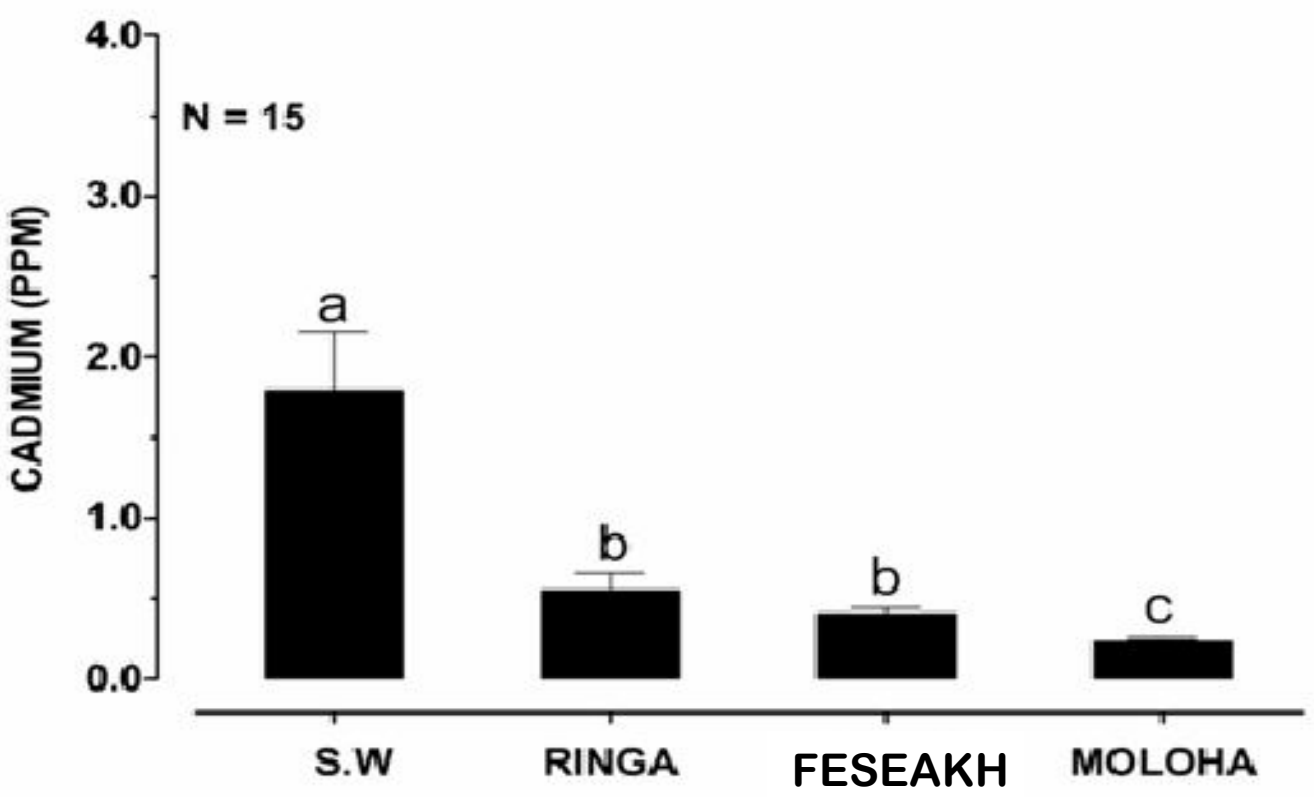

Figure (2): Cadmium levels in different types of fishs $n=15$ The letters on bar a,b,c denotes the significance difference of Cadmium levels among the different types of fishs $(\mathrm{P}<0.05)$.

\section{DISCUSSION}

Most lead concentrations that are found in the environment due to human activities. The high level of lead mainly returned to industrial discharges from super phosphate factories, traffics of high way or motor vehicles as well as the extensive use of agrochemicals such as fertilizers, pesticides and growth promoters. (Mason, 1991).

Our results reveled that the mean values \pm SD of lead in Moloha, Feseakh, Ringa and salted water for Moloha were $2.795 \pm 0.419,2.890 \pm 0.512,2.482 \pm$ 0.331 and $1.66 \pm 0.502 \mathrm{mg} / \mathrm{kg}$ wet weight respectively. (Table and figure 1). These results were higher than the permissible limit recorded by Egyptian Organization of Standardization and Quality EOSQC at 1993 (0.1 ppm) and in 1992 by FAO/WHO (0.5 ppm). These results were lower than that recorded by Dural et al. (2007), El-Tahan et al. (1999). Also Bakhiet and khgalie, (2013) who found that the lead content of fresh fish and salted fish in
Sudan $(15 \%, 20 \%, 25 \%)$ were 0.324 and $0.330,0.477$ and $0.464 \mathrm{mg} / 100 \mathrm{~g}$ respectively. Also Dural et al. (2007); El-Tahan et al. (1999) agreement with the previous results While Yosef and Ghada (2011) found $0.444 \pm 0.081 \mathrm{mg} / \mathrm{kg}$ as a lead concentration in salted Fish.

Figure (1) revealed no significance difference in lead levels between Moloha, Feseackh and Ringa but there are significance difference between those and salted water for Moloha $(\mathrm{P}<0.05)$. Metals dissolved in water may be accumulated by direct adsorption to body surfaces (Mason, 1991).

Cadmium pollution occur from many industrial companies as those of stabilized for plastics, sewage sludge that applied as fertilizers in land (Mason, 1991). Cadmium may accumulate in the human body and may induce kidney dysfunction, gastroenteritis, skeletal damage and reproductive deficiencies (Tuzen and Soylak, 2007). International Agency For Research has determined that the cadmium is probably carcinogenic to human (Stanley, 2004). 
As shown in table (2). Cadmium mean levels in Moloha, Fesekh, Ringa and salted water for Moloha were $0.244 \pm 0.018,0.406 \pm 0.138,0.549 \pm 0.422$ and $1.796 \pm 1.38 \mathrm{mg} / \mathrm{kg}$ wet weight respectively. Gutenmann et al. (1988) recorded that frequently used food safety limit for cadmium in sea food is 2 ppm. In 1993, Food and Agriculture Organization (FAO) recorded $0.5 \mathrm{ppm}$ as the limit for cadmium. While WHO, (1990) indicated 2 ppm as the cadmium permissible limit for sea food. Data from reliable analysis performed in several countries (Elinder, 1985); WHO/FAO, 2003) indicate that most food stuffs have cadmium concentrations in the range 0.005-0.100 $\mathrm{mg} / \mathrm{kg}$ (mean values, wet weight). Maximum level for cadmium must not exceed 0.1 ppm wet weight (EOSQC, 1993). Our results revealed high level of cadmium than the permissible limit previously recorded by EOSQC,1993 and FAO/WHO,1990) In previous studies by Youssef et al. (2003) who found $(0.003 \pm 0.001)$ as a mean level of cadmium in salted fish. Bakhiet and Khogli. (2013) recorded a cadmium content of fresh fish and salted fish $(15 \%, 20 \%, 25 \%)$ as 0.175 and $0.181,0.179,0.182$ $\mathrm{mg} / 100 \mathrm{~g}$ respectively. Yosef and Ghada (2011) recorded $0.164 \pm 0.031 \mathrm{mg} / \mathrm{kg}$ as cadmium concentration in salted fish.

Analytical data obtained from this study revealed that the cadmium concentrations in preserved salted water for Moloha were higher than the permissible limit that mentioned before. Therefore a serious heath risk associated with the consumption of salted water for Moloha, must be concerned and reduced.

As showen in Figure (2), there was a significance difference between preserved salted fish water of Moloha and those muscle of Ringa, Moloha and Feseakh, while non significance difference between those of Faseakh and Ringa. On the other hand both types Feseakh and Ringa were shown significance difference from those of Moloha, $(\mathrm{P}<0.05)$.

The variation of lead and cadmium concentration in different salted and smoked fish analyzed could be attributed to the fact that some fish are older in age than others cumulative effects. The level of contaminants in fish is influenced by the duration of exposure of fish to contaminants in water, feeding habit of fish, concentrations of contaminants in water columm, water chemistry, contamination of fish during handling and processing, quality and shelf of salted and smoked fish. (Boadi et al., 2011).

\section{CONCLUSION}

The present study show that precaution measures must be taken to prevent further contamination of salted and smoked fish by heavy metal especially lead and cadmium. Also more research and assessments of seafood quality is needed in our countries to provide more data and help safe guard the health of human.

\section{REFERENCES}

Bakhiet, H.H. and Khogalie, F.A. (2013): Effect of different salt concentration on total bacterial count and heavy metal composition of the fish Hydrocynus spp. J. of Animal and Feed Research., 3 (2): 87-90.

Berhimpon, S.; Souness, R.A.; Driscoll, R.H.; Buckle, K.A. and Edwards, R.A. (1991): Salting behavior of yellow tail (Trachurus muscullochi Nichols). J. Food Prot. Preserve. 15 (2): 101-114.

Boadi, N.O.; Twumasi, S.K.; Badn, M. and Osei, 1. (2011): Heavy metal contamination in canned fish marketed in Ghana. Am. J. Sci. Ind. Res., 2 (6): 877-882.

Dural, M.M.; Goksu, Z.L. and Ozak, A.A. (2007): Investigations of heavy metal level in economically important fish species captured from the Tuzal Lagoon, Food Chem., 102: 415- 421.

Elinder, C.G. (1985): Cadmium, Uses, Occurance and Intake. In "cadmium and Health" A. Toxicological and Epidemiological Apprasial, Volume 1, pp 23-63.

El-Tahan, M.H.; Hassan, S.A.; EL-Awamry, Z.K. and Hamza, A.S. (1999): Studies of some heavy metals and nutritive values in salted fish in Egypt. J. Egyptian German Society of Zoology, 29 41-54.

EOSQC (Egyptian Organization of Standardization and Quality Control) (1993): Maximum residue limits for heavy metals in food, Ministry of Industry No. 2360: 5, Cairo, Egypt.

FAO Food and Agriculture Organization (1993): Compilation of Legal limits for hazardous substances in fish and fishery products, FAO fishery circular No. 464, pp. 5-100.

FAO/WHO (1990): "Guide lines for seafood Quality" $2^{\text {nd }}$ ed., V (1), Recommendation, WHO Geneva.

FAO/WHO (1992): Codex Alimentarius Commission, standard program codex committee on food additives and contaminants $24^{\text {th }}$ session, Hague, 23-28 March.

Friberg, L. (1984): Cadmium and kidney. Environ Health Perspect 54: 1-11.

Guttenmann, W.H.; Bache, C.A.; McCahan, J.B. and Lisk, D.J. (1988): "Heavy Metals and Chlorinated Hydrocarbons in Marine Fish Products" Nutri. Reports Irt., 38, 1157-1161.

Hu, H. (2000): Exposure to metals, Prim. Care 2, 983-996.

Mansour, S.A. and Sidky, M.M. (2002): Ecotoxicological stndies. 3 Heavy metals contaminating water and fish from fayoum Governorate, Egypt. Food Chemistry 78: $15-22$.

Mason, C.F. (1991): Biology of freshwater pollution. $2^{\text {nd }}$ Edition L ongman New York. P. 351. 
Pratap, H.B. and Wendelaar, S.E. (2007): Calcium haemostasis in low and high calcium water acclimatized oreochromis mossombicus exposed to ambient and dietary cadmium. J. Environ. Biol., 28: 385-393 PMID: 17929754.

Sorensen, E.M. (1991): Cadmium metal poisoning in fish. CRC press, Boca Raton, Flourida.

Stanley, T.O. (2004): Food and Nutritional Toxicology, By CRC press LLC, BOCa Raton, London, New York, Washington, D.C.

Steel, R.G.; Torrie, J.H. and Dinkey, D.A. (1996): Principles and procedures of statistics, $2^{\text {nd }} \mathrm{Ed}$., Mc Graw Hill Book Co., Singapore.

Tuzen, M. and Soylak, M. (2007): Determination of trace metals in canned fish marketed in Turkey. Food Chem. 101 (4): 1378-1382.

Wheaton, F.W. and Lawson, T.B. (1985): Processing of aquatic food products. Awiely inter science publication P. 231-232.
WHO. (1990): "Guidelines for Sea food Quality." $2^{\text {nd }}$. Ed.,V(1), Recommendation, WHO Geneva.

WHO/FAO. (2003): Joint Expert Committee on Food Additives and Contaminants.

Yilmaz, F.M.; Ozdemir, A.; Demirak, A. and Tuna, L. (2007): Heavy metal levels in two fish speices leucissus cephalus and lepomis gibbosus, Food, Chem, 100: 830-835.

Yosef, T.A. and Ghada, M.G. (2011): Assessment of some heavy metal content in fresh and salted (Feseakh) Mullet fish collected from ElBurullus lake, Egypt, J. of Americ. Scien. 7 (10) 137.

Youssef, M.S.; Abo-Dohab, N.F. and Farghaly, R.M. (2003): Studies on Mycological status of salted fish "Moloha" in Upper Egypt. J. of Microbiology 31 (3): 166-172.

Zugarramurdi, A. and Lupin, H.M. (1980): Amodel to explain observed behavior on fish salting. J. Food Sci., 45 (5): 1305-1311.

\section{تقييم الرصاص والكادميوم في بعض الأسماك المصرية المملحة والمدخنة}

\section{ناهد محمود عبد العزيز ، زكريا مختار زكى}

Email: Nahedvet2012@yahoo.com

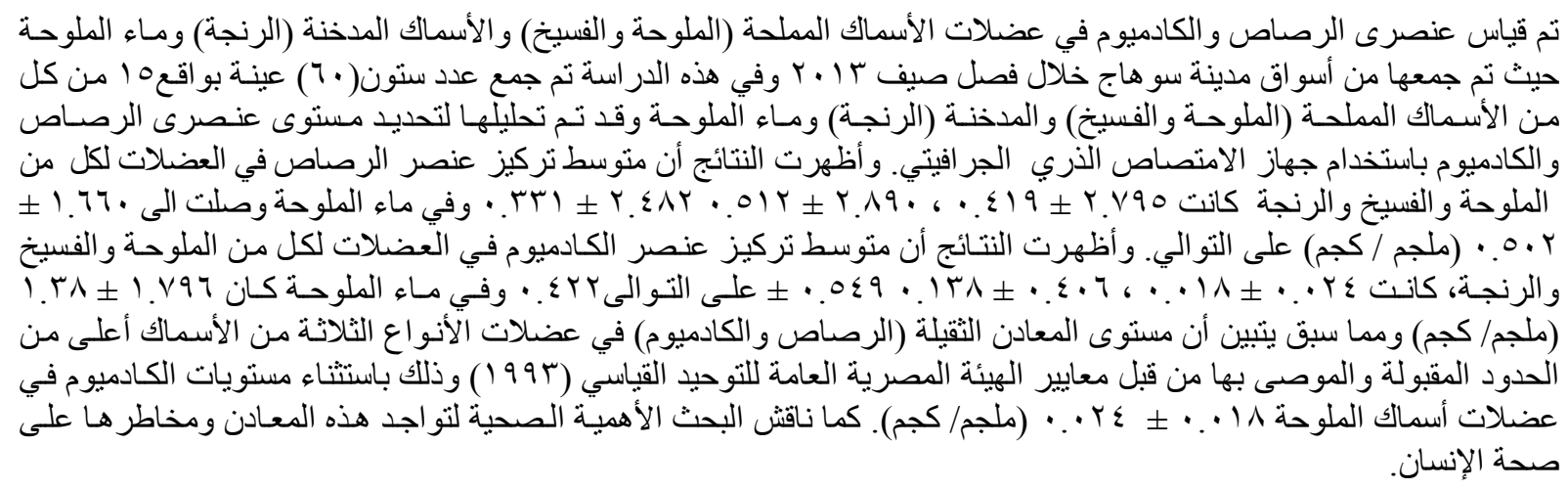

